\title{
Rancang Bangun Aplikasi untuk Pemetaan Tingkat Kemiskinan Masyarakat Berbasis Perangkat Bergerak
}

\author{
Risky Dwi Setiyawan, Dwi Sunaryono, Rizky Januar Akbar \\ Jurusan Teknik Informatika, Fakultas Teknologi Informasi, Institut Teknologi Sepuluh Nopember (ITS) \\ Jl. Arief Rahman Hakim, Surabaya 60111 Indonesia \\ e-mail:dwi@if.its.ac.id,rizky@if.its.ac.id,risky.setiyawan22@gmail.com
}

\begin{abstract}
Abstrak-Permasalahan pada penelitian ini adalah proses survei tingkat kesejahteraan masyarakat yang dilakukan oleh Badan Pusat Statistik (BPS). Survei yang dilakukan selama ini masih secara konvensional dan membutuhkan waktu cukup lama baik dalam pendataan, validasi maupun pengolahan data. Selain itu, Badan Perencanaan Pembangunan Daerah (Bappeda) selaku pihak yang akan memberikan program pemerintah juga kesulitan untuk mendapatkan rekomendasi berupa daftar masyarakat dari hasil survei tersebut, karena pengolahan data dilakukan secara terpusat oleh Tim Nasional Percepatan penanggulangan Kemiskinan (TNP2K). Belum lagi permasalahan pelaporan sasaran program yang sulit dilacak pada Bappeda itu sendiri. Maka dari itu, diperlukan aplikasi perangkat bergerak (mobile) untuk survei serta aplikasi web untuk pengawasan dan melakukan proses pendukung lainnya. Aplikasi mobile digunakan untuk melakukan survei secara langsung. Sedangkan pada web, data survei yang masuk dapat dipantau, divalidasi sekaligus menampilkan hasil pengolahan data survei yang berupa tingkat kesejahteraan masyarakat. Sistem ini didukung oleh metode AHP dan K-Means untuk memproses data survei dan melakukan klasifikasi berdasarkan tingkat kesejahteraan masyarakat. Hasil pengujian menunjukkan bahwa aplikasi yang dibangun dapat digunakan untuk survei tingkat kesejahteraan masyarakat. Aplikasi mobile dan web dapat saling terhubung secara realtime. Metode yang digunakan juga bisa memberikan rekomendasi program pemerintah berupa data masyarakat berdasarkan tingkat kesejahteraan masing-masing. Selain itu, pengguna, dalam hal ini adalah pihak BPS dan Bappeda, mempunyai ketertarikan terhadap sistem yang dibangun.
\end{abstract}

Kata Kunci-AHP, Android, Indeks Kemiskinan, K-Means, Tingkat Kesejahteraan

\section{PENDAHULUAN}

$\mathrm{P}$ ERMASALAHAN kemiskinan di Indonesia, sudah seperti permasalahan pokok yang selalu menjadi sorotan hingga sampai saat ini. Tidak sedikit program-program pemerintah yang digalakkan untuk menekan tingkat kemiskinan pada masyarakat, seperti halnya Bantuan Operasional Sekolah, Kartu Indonesia Sejahtera, Kredit Usaha Rakyat dan lain sebagainya. Salah satu badan yang dipercayai untuk memantau tingkat kemiskinan masyarakat adalah Badan Pusat Statistik (BPS). Menurut data BPS yang baru, persentase penduduk miskin di daerah perkotaan pada September 2014 sebesar 8,16 persen, naik menjadi 8,29 persen pada Maret 2015. Sementara persentase penduduk miskin di daerah pedesaan naik dari 13,76 persen pada September 2014 menjadi 14,21 persen pada Maret 2015 [1]. Dapat kita lihat, bahwasannya tingkat kemiskinan di Indonesia dalam satu tahun terakhir ini mengalami peningkatan.

Salah satu faktor penting dalam penanganan kemiskinan ini ialah data yang akurat dan program pemerintah yang tepat sasaran. Saat ini, pendataan tingkat kemiskinan masyarakat, khususnya di Kabupaten Madiun, masih dilakukan secara konvensional (menggunakan kertas kemudian dimasukkan kedalam sistem) dan tidak menampilkan program pemerintah apa saja yang seharusnya didapatkan dari hasil pendataan tersebut. Dalam aplikasi yang dibangun ini menggunakan tools Android, dimana proses pendataan tidak lagi menggunakan kertas dan juga praktis untuk digunakan, selain itu juga menggunakan website untuk manajemen kebutuhan lainnya. Selain dalam hal kemudahan pendataan, aplikasi ini dapat menampilkan rekomendasi berupa daftar masyarakat yang seharusnya mendapatkan program pemerintah sesuai tingkat kesejahteraan masing-masing. Penentuan rekomendasi program pemerintah ini menggunakan metode Analytic Hierarchy Process (AHP) dan K-Means sebagai pendukung proses pengambilan keputusan.

Dilihat dari pemaparan di atas, aplikasi ini diharapkan mampu memberikan data yang akurat terkait tingkat kemiskinan masyarakat. Dengan demikian program-program pemerintah yang direkomendasikan oleh aplikasi ini bisa lebih tepat sasaran. Dari sisi perangkat lunak, diharapkan aplikasi ini juga mudah digunakan dan mampu mengolah data secara cepat, karena jumlah penduduk yang sangat banyak sehingga membutuhkan proses pengolahan data yang lebih cepat.

\section{TINJAUAN PUSTAKA}

\section{A. Definisi Kemiskinan}

Kemiskinan secara konseptual dibedakan menurut kemiskinan relatif dan kemiskinan absolut, dimana perbedaannya terletak pada standar penilaiannya. Standar penilaian kemiskinan relatif merupakan standar kehidupan yang ditentukan dan ditetapkan secara subyektif oleh masyarakat setempat dan bersifat lokal serta mereka yang berada dibawah standar penilaian tersebut dikategorikan sebagai miskin secara 
relatif. Sedangkan standar penilaian kemiskinan secara absolut merupakan standar kehidupan minimum yang dibutuhkan untuk memenuhi kebutuhaan dasar yang diperlukan, baik makanan maupun non makanan. Standar kehidupan minimum untuk memenuhi kebutuhan dasar ini disebut sebagai garis kemiskinan [2].

\section{B. Metodologi Pendataan Kemiskinan}

Metode pemilihan sampel dilakukan dalam 6 tahap. Pada tahap pertama dipilih 7 propinsi secara purposive (sengaja) namun dapat mewakili wilayah barat dan timur Indonesia, serta wilayah urban dan rural. Ketujuh propinsi tersebut adalah SUmatera Selatan, DKI Jakarta, DI Yogyakarta, Jawa Timur (mewakili wilayah barat), Nusa Tenggara Barat, Kalimantan Barat, dan Sulawesi Selatan (mewakili wilayah timur). Tahap kedua adalah memilih 2 kabupaten/kota dari masing-masing propinsi kecuali DKI Jakarta 3 kota secara purposive. Dari masing-masing kabupaten/kota, dipilih sampel 2 kecamatan secara purposive. Sampai dengan tahap ketiga, pemilihan sampelnya dilakukan BPS Pusat.

Selanjutnya tahap keempat, yaitu pemilihan desa dilakukan oleh petugas BPS Propinsi dimana pada setiap kecamatan dipilih 2 desa. Tahap kelima adalah pemilihan 2 Rukun Tetangga (RT) pada setiap desa yang dilakukan oleh petugas lapangan (BPS Kabupaten/Kota) dengan pertimbangan kondisi sosial ekonomi masyarakat RT tersebut heterogen. Tahap terakhir (keenam) adalah pemilihan rumah tangga dimana pada setiap RT dipilih 30 rumah tangga dengan cara systematic sampling yang distratakan berdasarkan tingkat kesejahteraannya. Pemilihan sampel rumah tangga didasarkan pada hasil pendaftaran rumah tangga di masing-masing RT. Perhitungan interval sampel dan pemilihan angka random pertama (R1) untuk pemilihan sampel rumah tangga dilakukan pada setiap RT terpilih [3].

\section{Analytic Hierarchy Process}

Analitycal Hierarchy Process (AHP) merupakan suatu pendekatan praktis untuk memecahkan masalah keputusan kompleks yang meliputi perbandingan alternatif. AHP juga memungkinkan pengambil keputusan menyajikan hubungan hierarki antar aktor, atribut, karakteristik atau alternatif dalam lingkungan pengambilan keputusan. Dengan ciri ciri khusus hierarki yang dimilikinya, masalah kompleks yang tidak terstruktur dipecah dalam kelompok-kelompoknya [4]. Adapun diagram hierarki AHP ditunjukkan pada Gambar 1.

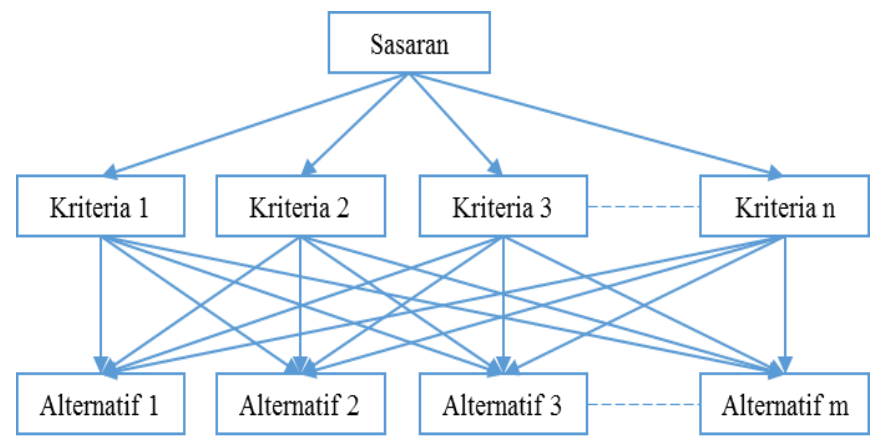

Gambar 1. Diagram Hierarki Analytical Hierarchy Process (AHP)

\section{K-Means}

K-Means Clustering merupakan salah satu metode yang dapat digunakan untuk membagi sejumlah objek ke dalam partisi-partisi berdasarkan kategori-kategori yang ada dengan melihat titik tengah yang diberikan. Pengelompokan objek dilihat dari jarak objek dengan titik tengah yang paling dekat. Setelah mengetahui titik tengah terdekat, objek tersebut akan diklasifikasikan sebagai anggota dari kategori tersebut [5].

\section{ANALISIS DAN PERANCANGAN SISTEM}

\section{A. Domain Permasalahan}

Badan Pusat Statistika (BPS) dalam setiap 4 tahun sekali melakukan survei tingkat kesejahteraan masyarakat. Survei ini dilakukan secara serentak di masing-masing daerah, dimana terdapat surveyor tingkat desa yang melakukan pendataan secara langsung dan surveyor tingkat kecamatan yang bertugas melakukan controlling terhadap surveyor tingkat desa. Dalam pelaksanaannya selama ini, survei yang dilakukan oleh surveyor masih secara manual. Dimana alurnya dimulai dari pendataan informasi masing-masing kepala keluarga dengan menggunakan formulir berupa kertas. Kemudian surveyor tingkat kecamatan melakukan validasi awal data dan menyerahkan ke BPS. Dari BPS data baru divalidasi akhir dan dikirim ke Tim Nasional Percepatan Penanggulangan Kemiskinan (TNP2K).

Data survei yang diolah oleh TNP2K ini akan menghasilkan informasi berupa tingkat kesejahteraan masyarakat. TNP2K membagi tingkat ksesejahteraan masyarakat menjadi 3 bagian seperti pada Tabel B.1 baris ke-11. Kemudian oleh Badan Perencanaan Pembangunan Daerah (Bappeda), pembagian 3 tingkatan tersebut disebut dengan istilah hampir miskin untuk kode tingkat kesejahteraannya 1 , kode 2 menunjukkan miskin dan sangat miskin untuk kode tingkat kesejahteraan 3. Hasil ini nantinya akan digunakan oleh pemerintah daerah sebagai referensi untuk menentukan program pemerintah.

Maka dari itu, solusi yang ditawarkan pada penelitian ini adalah pembuatan aplikasi yang menggabungkan konsep survei dari BPS dan kebutuhan pemerintah daerah untuk menentukan program pemerintah terhadap masyarakat miskin.

\section{B. Analisis}

Pembuatan aplikasi untuk pendataan dan pemetaan tingkat kemiskinan masyarakat ini menggunakan perangkat bergerak (Android) dan website. Perangkat Android dapat digunakan untuk melakukan survei dengan cara memasukkan seluruh informasi masyarakat yang dibutuhkan saat pendataan. Aplikasi Android ini juga dapat melakukan pre-validation, dimana seluruh informasi yang dibutuhkan tidak mungkin bisa diisi diluar kriteria atau bahkan tidak diisi.

Setelah informasi tersebut dimasukkan, kemudian data tersebut langsung dikirim ke server/pusat data. Aplikasi ini juga dapat mengambil lokasi dimana surveyor melakukan pendataan. Data yang telah dikirim ini kemudian dapat dipantau secara langsung dengan menggunakan aplikasi pada website. Dengan menggunakan aplikasi pada website ini, 
memungkinkan untuk dlakukannya controlling secara realtime, dan juga dapat dilakukan validasi data terakhir secara langsung.

Selain itu, aplikasi website ini juga dapat menampilkan rekomendasi siapa saja masyarakat yang akan mendapatkan program pemerintah dengan memperlihatkan tingkat kemiskinan masing-masing kepala keluarga yang telah disurvei pada daerah terkait. Kasus penggunaan aplikasi ini dapat dilihat pada Gambar 2.

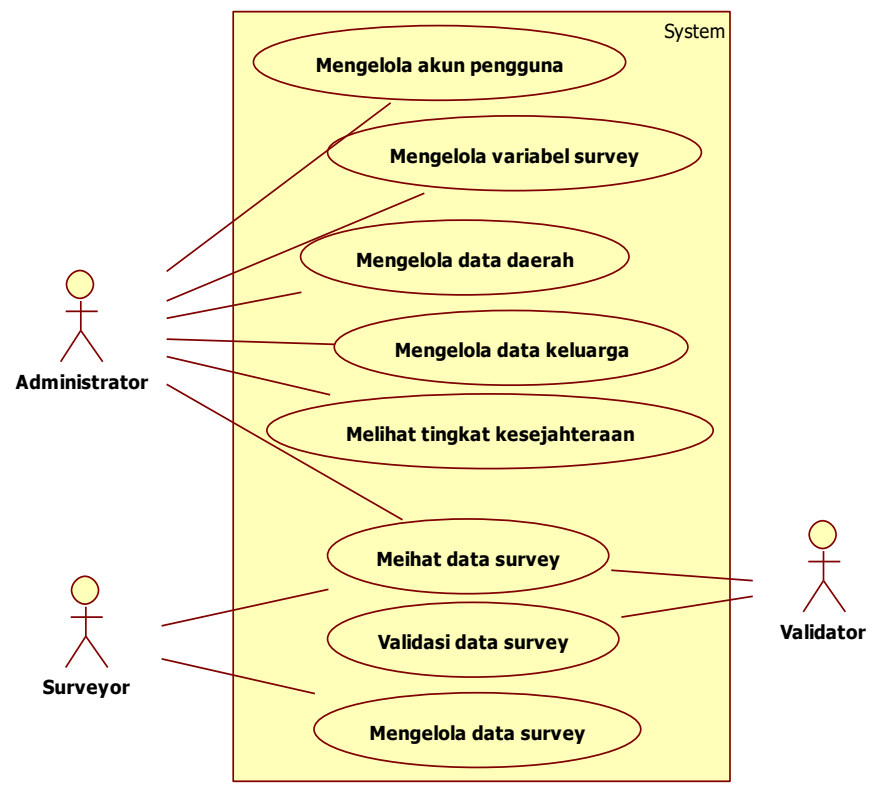

Gambar 2. Diagram Kasus Penggunaan

\section{Perancangan Algoritma}

Metode yang digunakan untuk menentukan tingkat kemiskinan masyarakat adalah Analytic Hierarchy Process (AHP) dan K-Means. AHP digunakan untuk menghitung nilai dari setiap variabel survei, kemudian $K$-Means digunakan untuk melakukan clustering dan klasifikasi dari nilai AHP kedalam tingkat kesejahteraan masyarakat. Berikut ini adalah tahapan untuk menentukan tingkat kesejahteraan masyarakat.

\section{Menentukan variabel survei}

Pada tahap ini, variabel survei harus ditentukan terlebih dahulu. Dimana variabel tersebut yang nantinya digunakan untuk mendapatkan informasi survei. Adapun kode survei yang digunakan untuk melakukan survei dan perhitungan hasil survei nantinya menggunakan variabel yang ada pada Tabel 1 .

Tabel 1.

Variabel survei dan kategori untuk penilaian

\begin{tabular}{cll}
\hline \hline No & Definisi Variabel & \multicolumn{1}{c}{ Kategori/Kode } \\
\hline 1 & Jenis Kelamin & 1. Laki-Laki \\
& Kepala Rumah & 2. Perempuan \\
& Tangga & \\
2 & Umur Kepala & - \\
& $\begin{array}{l}\text { Rumah Tangga } \\
\text { saat Pendataan }\end{array}$ & \\
3 & Pendidikan & 0. Tidak punya ijazah; 1. SD/sederajat; \\
& Kepala Rumah & 2. SMP/sederajat; 3. SMA/sederajat \\
& Tangga & 5. Perguruan Tinggi \\
\hline \hline
\end{tabular}

\begin{tabular}{|c|c|c|}
\hline 4 & $\begin{array}{l}\text { Lapangan Usaha } \\
\text { Kepala Rumah } \\
\text { Tangga }\end{array}$ & $\begin{array}{l}\text { 1. Pertanian (padi \& palawija) } \\
\text { 2. Hortikultura } \\
\text { 3. Perkebunan } \\
\text { 4. Perikanan tangkap } \\
\text { 5. Perikanan budidaya } \\
\text { 6. Peternakan } \\
\text { 7. Kehutanan \& pertanian lain } \\
\text { 8. Pertambangan / penggalian } \\
\text { 9. Industri pengolahan } \\
\text { 10.Listrik \& gas } \\
\text { 11.Bangunan / konstruksi } \\
\text { 12.Perdagangan } \\
\text { 13. Hotel \& rumah makan } \\
\text { 14.Transportasi \& pergudangan } \\
\text { 15.Informasi \& komunikasi } \\
\text { 16. Keuangan \& asuransi } \\
\text { 17.Jasa pendidikan/jasa kesehatan/jasa } \\
\quad \text { kemasyarakatan, pemerintahan dan } \\
\quad \text { perorangan } \\
\text { 18.Lainnya }\end{array}$ \\
\hline 5 & Jumlah Keluarga & - \\
\hline 6 & $\begin{array}{l}\text { Status penguasaan } \\
\text { bangunan tempat } \\
\text { tinggal }\end{array}$ & $\begin{array}{l}\text { 1. Milik sendiri; } \\
\text { 2. Kontrak/Sewa } \\
\text { 3. Lainnya }\end{array}$ \\
\hline 7 & Jenis Atap Terluas & $\begin{array}{l}\text { 1. Beton; 2. Genteng; 3. Sirap; 4. Seng; } \\
\text { 5. Asbes; 6. Ijuk/rumbai; 7. Lainnya }\end{array}$ \\
\hline 8 & $\begin{array}{l}\text { Jenis Dinding } \\
\text { Terluas }\end{array}$ & $\begin{array}{l}\text { 1. Tembok; 2. Kayu; } \\
\text { 3. Bambu; 4. Lainnya }\end{array}$ \\
\hline 9 & Jenis Lantai & $\begin{array}{l}\text { 1. Bukan tanah / bamboo; } \\
\text { 2. Tanah; 3. Bambu }\end{array}$ \\
\hline 10 & Sumber air minum & $\begin{array}{l}\text { 1. Air Kemasan; } 2 \text {. Air Ledeng } \\
\text { 3. Air Terlindung; } 4 \text {. Air Tidak Terlindung }\end{array}$ \\
\hline 11 & $\begin{array}{l}\text { Sumber } \\
\text { penerangan utama }\end{array}$ & $\begin{array}{l}\text { 1. Listrik PLN; 2. Listrik non-PLN; } \\
\text { 3. Tidak ada listrik }\end{array}$ \\
\hline 12 & $\begin{array}{l}\text { Bahan bakar } \\
\text { utama untuk } \\
\text { memasak }\end{array}$ & $\begin{array}{l}\text { 1. Listrik/Gas/Elpiji; } \\
\text { 2. Lainnya }\end{array}$ \\
\hline 13 & $\begin{array}{l}\text { Fasilitas tempat } \\
\text { buang air besar }\end{array}$ & $\begin{array}{l}\text { 1. Sendiri; 2. Bersama/Umum; } \\
\text { 3. Tidak ada }\end{array}$ \\
\hline 14 & $\begin{array}{l}\text { Tempat } \\
\text { pembuangan akhir } \\
\text { tinja }\end{array}$ & $\begin{array}{l}\text { 1. Tangki/SPAL; } \\
\text { 2. Lainnya }\end{array}$ \\
\hline
\end{tabular}

2. Menentukan bobot dan perhitungan variabel survei

Dari variabel yang telah ditentukan sebelumnya, pada tahapan ini adalah memberikan bobot dari masing-masing variabel. Bobot ini nantinya akan digunakan untuk perhitungan selanjutnya menggunakan AHP.

Variabel survei akan dibagi menjadi 2 sub variabel, yaitu Sumber Daya Manusia (SDM) dan Infrastruktur. Pembagian variabel kedalam 2 sub variabel ini dilakukan untuk menormalkan dan mengkategorikan setiap variabel kedalam kategori yang sama. Untuk lebih jelasnya, bisa dilihat dari Tabel 2.

Tabel 2.

Pengelompokan Variabel Survei

\begin{tabular}{cll}
\hline \hline No & Sub variabel & \multicolumn{1}{c}{ Detail Variabel } \\
\hline 1 & Sumber Daya & Jenis kelamin kepala rumah tangga \\
& Manusia (SDM) & Umur Kepala Rumah Tangga saat Pendataan \\
& & Pendidikan kepala rumah tangga \\
& & Lapangan usaha kepala rumah tangga \\
& & Jumlah keluarga \\
2 & Infrastruktur & Status penguasaan bangunan tempat tinggal \\
& & Jenis atap terluas \\
& & Jenis dinding terluas \\
\hline \hline
\end{tabular}




\author{
Jenis lantai \\ Sumber air minum \\ Sumber penerangan utama \\ Bahan bakar utama untuk memasak \\ Fasilitas tempat buang air besar \\ Tempat pembuangan akhir tinja
}

\section{Clustering Menggunakan K-Means}

Pada tahapan ini, data akan di-cluster menjadi 3 bagian dengan menggunakan tools WEKA. Langkah awal yaitu mengumpulkan data survei yang dijadikan data training. Data yang digunakan sebagai data training yaitu sebanyak 57.522 yang didapatkan dari hasil survei tingkat kemiskinan masyarakat di daerah Kabupaten Madiun pada tahun 2011. Selanjutnya data diolah dengan metode AHP seperti contoh di atas. Output dari AHP tersebut kemudian di-cluster menjadi 3 bagian, yaitu kategori hampir miskin, miskin dan sangat miskin. Metode K-Means ini menghasilkan batas dari setiap kategori, dimana batas-batas tersebut akan dijadikan referensi jika ada data baru masuk dan langsung dipetakan kedalam salah satu kategori tingkat kemiskinan. Pada Gambar 3 ini menunjukkan hasil dari pengolahan dataset menggunakaan metode AHP yang kemudiaan dipetakan dengan metode $K$-Means.

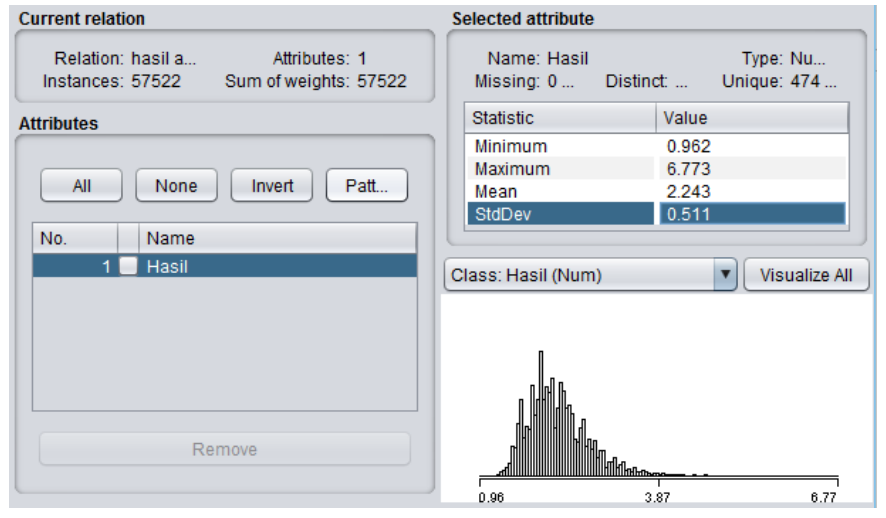

Gambar 3. Dataset Hasil AHP

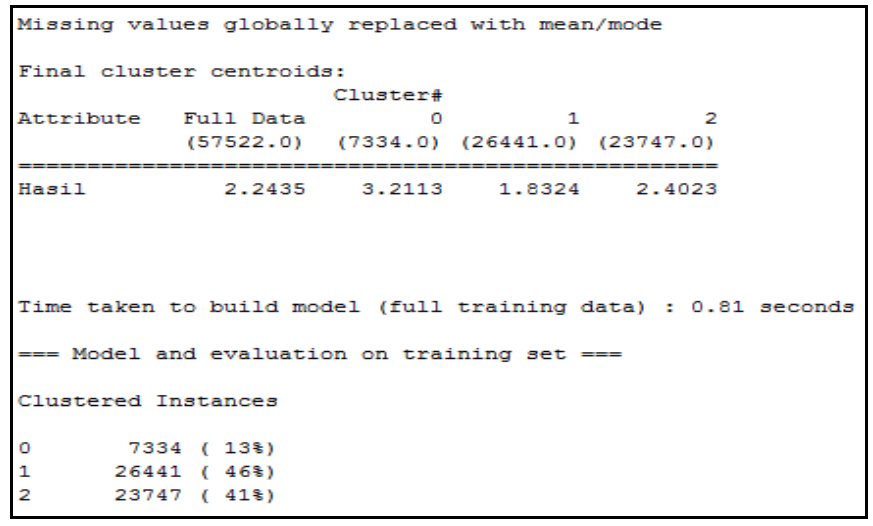

Gambar 4. Hasil Clustering

Dari Gambar 4 dapat disimpulkan bahwa titik pusat dari masing-masing cluster adalah cluster $1=1.8324$, cluster $2=$ 2.4023 dan cluster $3=3.2113$. Cluster disini nantiya disebut sebagai kategori tingkat kemiskininan, dimana cluster $1=$ hampir miskin, cluster $2=$ miskin dan cluster $3=$ sangat miskin. Karena titik pusat ini bersifat linier, maka masingmasing titik pusat akan dijadikan sebagai batasan untuk setiap kategori, dimana untuk menghitungnya menggunakan rata-rata dari masing-masing titik pusat antara cluster 1 dengan cluster 2 dan cluster 2 dengan cluster 3 . Sehingga diperoleh data baru sebagai berikut.

\section{Batas bawah (bb) cluster 2}

$\mathrm{bb}=($ titik pusat cluster $1+$ titik pusat cluster 2$) / 2$

$\mathrm{bb}=(1.18324+2.4023) / 2$

$\mathrm{bb}=4.2347 / 2$

$\mathrm{bb}=2.117$

2. Batas atas (ba) cluster 2

ba $=($ titik pusat cluster $2+$ titik pusat cluster 3$) / 2$

$\mathrm{ba}=(2.4023+3.2113) / 2$

$\mathrm{ba}=5.6136 / 2$

ba $=2.807$

Dari perhitungan di atas, maka didapatkan rentang dari setiap kategoti tingkat kesejahteraan berdasarkan hasil clustering. Adapun rentang dari setiap tingkat kesejahteraan terdapat pada Tabel 3.

Tabel 3 .

Batas Hasil Clustering

\begin{tabular}{clc}
\hline \hline No & Kategori & Rentang \\
\hline 1 & Hampir Miskin & $<2.117$ \\
2 & Miskin & $>=2.117,<2.807$ \\
3 & Sangat Miskin & $>=2.807$ \\
\hline \hline
\end{tabular}

\section{IMPLEMENTASI}

\section{A. Lingkungan Implementasi}

Aplikasi ini dibangun dengan menggunakan beberapa perangkat pendukung yang terdiri dari perangkat keras dan perangkat lunak.

Spesifikasi perangkat keras yang digunakan dapat dilihat pada Tabel 4.

Tabel 4.

Lingkungan Pengujian Perangkat Lunak

\begin{tabular}{l|ll}
\hline \hline $\begin{array}{l}\text { Aplikasi } \\
\text { Jenis }\end{array}$ & $\begin{array}{l}\text { Perangkat Bergerak } \\
\text { Perangkat }\end{array}$ & Web \\
Prosesor & Komputer \\
& Quad-core, 2260 MHz, & Intel Core i5-3230M CPU \\
Krait 400 $2,60 \mathrm{GHz}$ \\
Memori & $2 \mathrm{~GB}$ & 4 GB \\
Sistem Operasi & Android & Windows \\
Jenis Sistem & 4.4 .2 (Kit Kat) & Windows 10 (x64) \\
Operasi & & \\
\hline \hline
\end{tabular}

Sedangkan untuk perangkat lunak yang digunakan untuk mengembangkan aplikasi ini antara lain adalah Android Studio, Code Igniter dan PostgreSQL.

\section{B. Implementasi Proses Bisnis}

\section{Memasukkan data survei}

Fitur ini diimplementasikan pada web, namun sebagai web sevice untuk aplikasi Android. Untuk menambahkan data survei, aplikasi pada Android mengirim data masukan kepada server. Kemudian data tersebut diterima oleh server dan dilakukan penambahan data pada basis data 


\section{Validasi data survei}

Fitur ini diimplementasikan pada web yang berfungsi untuk melakukan validasi data survei. Data yang berhasil divalidasi juga akan secara otomatis menghitung hasil akhir dari data survei. Validasi ini bisa dilakukan oleh pengguna yang mempunyai hak akses validasi terhadap sistem.

3. Pengategorian tingkat kesejahteraan

Fitur ini diimplementasikan pada web yang berfungsi untuk melihat data kategori tingkat kemiskinan masyarkat. Data ini didapatkan dari hasil survei yang kemudian di petakan dengan table tingkat kesejahteraan. Sehingga sistem dapat menampilkan kelompok tingkat kesejahteraan masyarakat pada tingkat kecamatan masing-masing.

4. Menampilkan data tingkat kesejahteraan

Fitur ini diimplementasikan pada web yang berfungsi untuk melihat data masyarakat yang telah disurvei berdasarkan daerah dan kategori tingkat kesejahteraan. Data yang ditampilkan berupa nama target survei, alamat, dan tingkat kesejahteraannya.

\section{Monitoring data survei}

Fitur ini diimplementasikan pada web yang berfungsi untuk menampilkan rangkuman data survei. Rangkuman ini berisi data survei yang menjadi target, data yang sudah masuk, data valid dan data yang tidak valid. Dengan adanya fitur ini, pengguna dapat mengontrol survei secara realtime

\section{Implementasi Antarmuka}

Implementasi antarmuka ini terdiri dari antarmuka perangkat bergerak dan web. Pada perangkat bergerak, aplikas dapat menampilkan informasi survei dan form untuk memasukkan data suvei seperti pada Gambar 5. Data survei ini berisi tentang informasi dari target survei.

Sedangkan pada web, sistem juga dapat menampilkan informasi untuk monitoring survei dalam bentuk grafik seperti pada Gambar 6. Hasil dari keseluruhan survei juga dapat ditampilkan seperti pada Gambar 7, termasuk informasi lokasi dimana survei dilakukan. Selain menampilkan hasil survei secara keseluruhan, aplikasi ini juga dapat digunakan untuk validasi data survei.

Selanjutnya, pada aplikasi web juga terdapat antamuka tingkat kesejahteraan masyarakat seperti pada Gambar 8. Pada halaman antarmuka tingkat kesejahteraan masyarakat ini menampilkan pilihan daerah mulai dari tingkat provinsi hingga desa. Selain itu juga terdapat pilihan tingkat kesejahteraan. Hasil yang ditampilkan nantiya adalah data masyarakat yang telah disurvei berdasarkan kriteria yang dipilih.

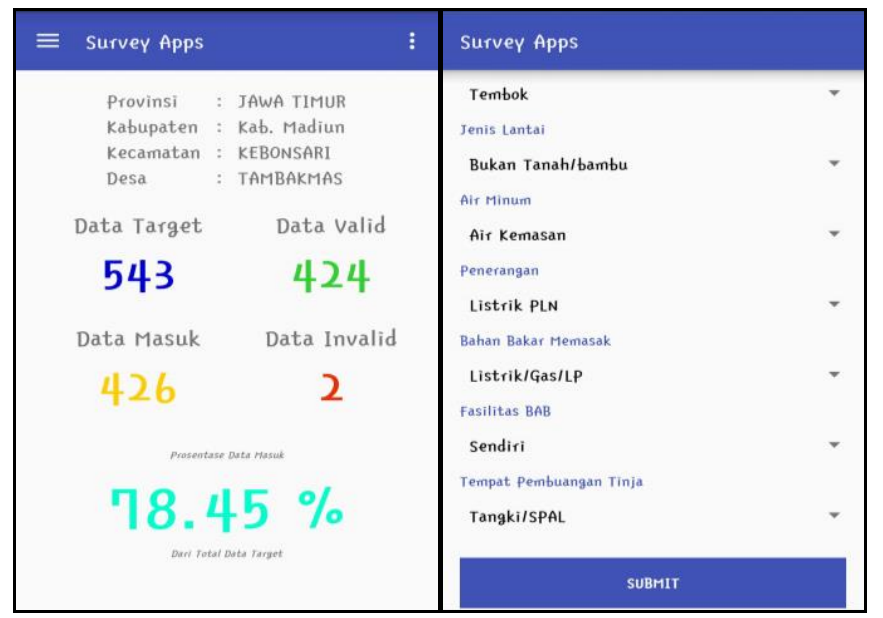

Gambar 5. Antarmuka Dashboard dan Form Masukan Survei Pada Perangkat Bergerak

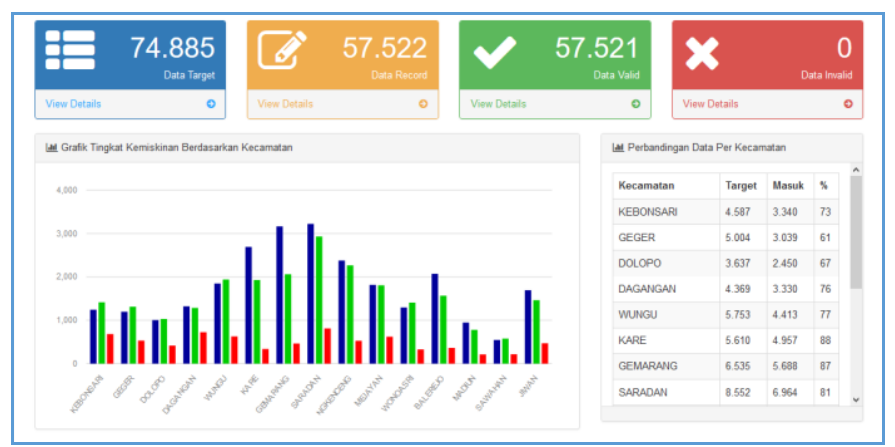

Gambar 6. Antarmuka Pemantauan Survei pada Web

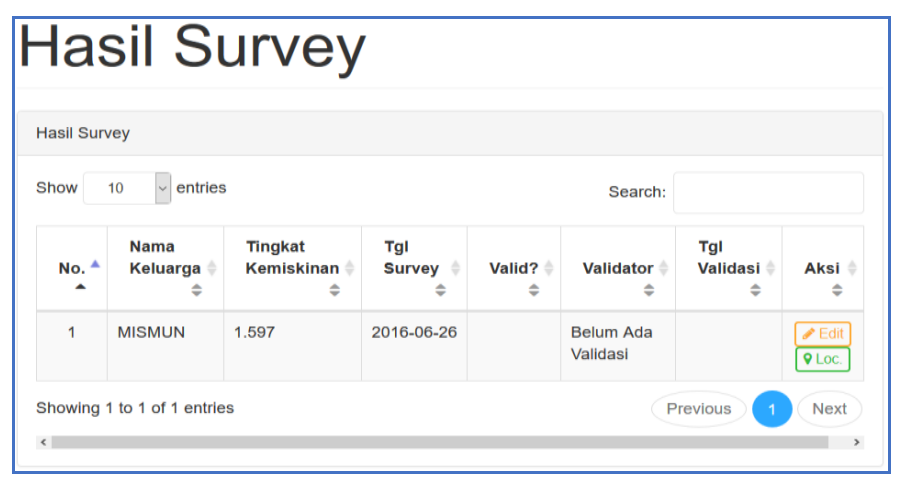

Gambar 7. Antarmuka Halaman Hasil Survei

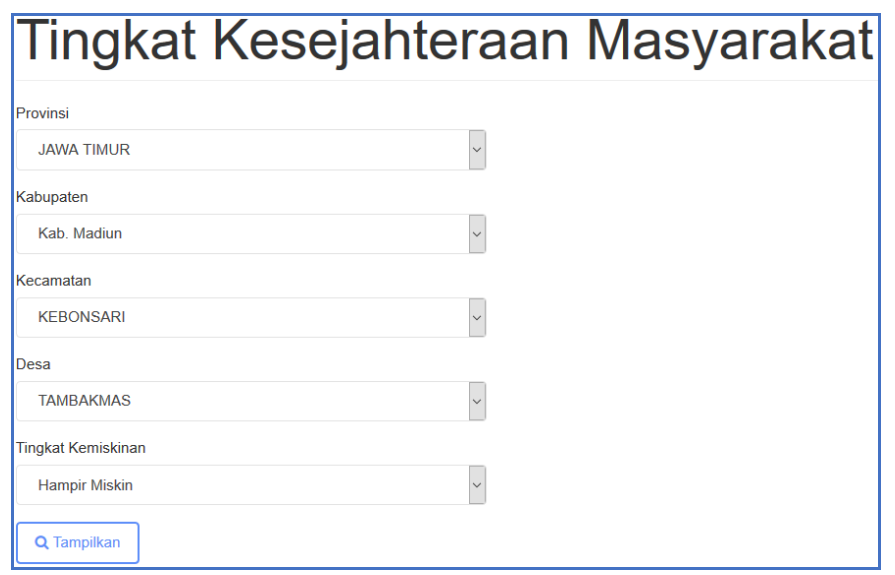

Gambar 8. Antarmuka Halaman Tigkat Kesejahteraan 


\section{PENGUJIAN DAN EVALUASI}

Pengujian pada aplikasi ini meliputi dua hal, yaitu pengujian secara fungsionalitas dan pengujian terhadap pengguna. Pengujian fungsionalitas, aplikasi dicoba berdasarkan fitur terkait. Dimana semua fungsionalitas sistem baik pada perangkat bergerak maupun pada web dapat berjalan dan digunakan sebagaimana kegunannya.

Sedangkan ujicoba pengguna ditujukan untuk orang yang mempunyai kepentingan terhadap alur didalam sistem, dalam hal ini yang dimaksud adalah BPS dan Bappeda. Hasilnya menunjukkan bahwa aplikasi ini dapat digunakan sebagai media baru untuk survei. Selain itu, fitur klasifikasi tingkat kesejahteraan masyarakat dianggap sangat berguna untuk memudahkan pemerintah daerah dalam mendapatkan rekomendasi program pemerintah.

\section{KESIMPULAN}

Dari hasil pengamatan selama proses perancangan, implementasi dan uji coba perangkat lunak yang dilakukan, dapat diambil kesimpulan sebagai berikut:

1. Dengan menggunakan aplikasi ini, surveyor cukup datang ke rumah warga dan memasukkan data survei pada aplikasi kemudian data langsung terkirim ke server. Dimana hasil yang sudah terkirim, dapat dilakukan validasi secara langsung hingga keluar hasil akhir berupa tingkat kesejahteraan masayarakat.

2. Pada studi kasus ini, metode AHP dapat digunakan untuk memproses variabel survei kedalam suatu nilai berdasarkan bobot masing-masing variabel, sedangkan K-Means digunakan untuk melakukan clustering (pengelompokan) data dari hasil AHP kedalam tingkat kesejahteraan. Dengan demikian aplikasi ini dapat digunakan sebagai referensi pemerintah daerah untuk memberikan program pemerintah.

3. Aplikasi web dan Android dapat terhubung secara realtime. Dengan demikian proses monitoring terhadap kegiatan suvei di lapangan dapat dilakukan setiap saat.

\section{UCAPAN TERIMA KASIH}

Penulis R.D mengucapkan terima kasih kepada Bappeda dan BPS Kabupaten Madiun yang telah memberikan bantuan dalam pengumpulan hingga analisis data, sehingga penelitian ini dapat diselesaikan oleh penulis.

\section{DAFTAR PUSTAKA}

[1] Badan Pusat Statistik, "PROFIL KEMISKINAN DI INDONESIA MARET 2015," Badan Pusat Statistik, Jakarta, 2015.

[2] Badan Pusat Statistik, "Kemiskinan : Metodologi," Badan Pusat Statistik, 8 May 2013. [Online]. Available: https://www.bps.go.id/Subjek/view/id/23\#subjekViewTab2|accordiondaftar-subjek1. [Accessed 13 July 2016].

[3] Badan Pusat Statistik, "Penghitungan dan Analisis Kemiskinan Makro Indonesia Tahun 2012," Katalog BPS, pp. 5-6, 1 December 2012.

[4] M. A. Asja, "Pengantar Penggunaan AHP (Analytical Hierarchy Process) dalam Pengambilan Keputusan," 7 April 2013. [Online]. Available: http://mawardisyana.blogspot.co.id/2013/04/pengantar-penggunaan-ahpanalytical.html. [Accessed 25 January 2016].
[5] Fadlika, "Rekaman Jejak Jejak," 14 Juni 2013. [Online]. Available: https://fadlikadn.wordpress.com/2013/06/14/tahap-tahap-k-meansclustering/. [Accessed 29 Mei 2016]. 